$81,91 \%$ [6]. Kiến thức về hoãn tiêm và chống chỉ định trong nghiên cứu của chúng tôi cũng chiếm tỷ lệ cao chỉ có trường hợp trẻ mới dùng globulin miễn dịch trong 3 tháng và trường hợp trẻ đang hoăc mới kết thúc điều trị corticoid trong vòng 14 ngày chỉ có $32,5 \%$ và $37,5 \%$ biết cần hoãn tiêm. Vì đây là kiến thức chuyên môn nên ít bà me biết đến.

Tỷ lệ các bà mẹ có hiểu biết về phản ứng phụ thông thường khi tiêm vắc xin như sốt $(90 \%)$, quấy khóc $(92,5 \%)$, đau sưng nhe chố tiêm $(88,3 \%)$, kiến thức cần biết về biểu hiện đưa trẻ đến CSYT như: sốt cao co giật $(98,3 \%)$, quấy khóc kéo dài, khóc thét, bỏ bú $(62,5 \%)$, khó thở, tím tái, thở nhanh $(89,2 \%)$. Kết quả này cao hơn của Phan Lê Thu Hằng [5].

4.2. Bàn luận về một số yếu tố liên quan đến kiến thức của các bà mẹ về tiêm chủng

Các yếu tố như tuổi tác, trình độ học vân, nghề nghiệp, kinh tế, số con không ảnh hưởng đến kiến thức của bà mẹ về tiêm chủng $(p>0,05)$

Trong các đối tượng được truyền thông hiệu quả có 83 người có kiến thức tốt về tiêm chủng, chiếm 95,4\%, sự khác biệt giữa nhóm kiến thức đạt và không đạt là có ý nghĩa thông kê $(p<0,05)$. Vì vậy cần đẩy mạnh công tác truyền thông tai địa phương cả về mặt nội dung và hình thức để nâng cao kiến thức của các bà mẹ về tiêm chủng.

\section{KẾT LUẬN}

1. Kiến thức của các bà me về tiêm chủng mở rộng. Các bà mẹ cho rằng tiêm chủng là rất quan trọng và quan trọng chiếm $72,5 \%$ và $25,8 \%$.

Có $75,8 \%$ các bà me biết được tác dụng của tiêm chủng nhưng vẫn có $21,7 \%$ hiểu sai.
Đa số hiểu đúng về các bệnh được phòng bởi tiêm chủng chỉ có $0,8 \%$ bà mẹ khồng biết. Chỉ có $3,4 \%$ và $0,8 \%$ các bà mẹ không biết về chống chỉ định tiêm và hoãn tiêm chủng.

Tỷ lệ có kiến thức tiêm chủng đạt là $90 \%$

2. Yếu tố ảnh hưởng đến kiến thức tiêm chủng của các bà mẹ. Yếu tố tuổi, trình độ học vấn, nghề nghiệp, kinh tế, số con không liên quan đến kiến thức tiêm chủng của các bà mẹ $(p>0,05)$

Hoạt động thông tin - giáo dục - truyền thông của địa phương có ảnh hưởng tích cực đến kiến thức của các bà mẹ về tiêm chủng, có ý nghĩa thống kê $(p=0,003)$.

\section{TÀI LIẸU THAM KHẢO}

1. Bộ Y tế (2014), Quyết định về phê duyêt "Kế hoạch truyên thông về việc tiêm chủng giai đoạn 2014-2016, 4282/QĐ-BYT.

2. WHO (2005), Thực hành tiêm chủng, GPXB số 58/QĐ-CXB cấp ngày 9/3/2005, Hà Nội.

3. Huỳnh Giao, Pham Lê An (2010), "Kiến thức thái độ của các bà me có con dưới 1 tuổi về tiêm chủng trong tiêm chủng mở rộng, thuốc chủng phối hợp, thuốc chủng Rotavirus, Human Papiloma Virus tại bệnh viện Nhi Đồng 2 và quận Tân Phú Tp Hồ Chí Minh năm 2009", tạp chí Ý học Tp.Hồ Chí Minh, Tập 14, Phụ bản số 2, trang 27.

4. Dương Anh Dũng (2017), "Thực trạng tiêm chủng, kiến thức, thái độ, thực hành tiềm chủng mở rộng tại 2 huyện biên giới của tỉnh Lạng Sơn năm $2015^{\prime \prime}$, tap chí Ý học dự phòng. Số 1 , trang 77.

5. Phan Lê Thu Hằng (2016), "Kiến thức và thực hành của các bà me có con đủ 12 tháng tuổi về tiêm chủng mở rộng tại huyện Thanh Hà, Hải Dương năm 2014 - 2015", tạp chí $Y$ học dự phòng. Số 5 , trang 158 .

6. Nguyền Thành Huế (2016), "Thực trạng tiêm chủng đầy đủ, đúng lịch 8 loại vacxin ở trẻ em dưới 1 tuổi và một số yếu tố liền quan tại khu vực ngoại thành thành phô Hà Nội năm 2016", Tạp chí Y học dự phòng.Số 3, trang 98.

\title{
THIẾT LÂP BẢNG ĐIỂM DỰA VÀO SIÊU ÂM ĐỂ TIÊN ĐOÁN SỐT XUẤT HUYẾT DENGUE Có SỐC Ở TRẺ EM
}

\section{TÓM TẮT.}

Đặt vấn đề: Siêu âm là phương tiện đơn giản giúp phát hiện dịch ổ bụng và màng phổi ở bệnh nhân

\footnotetext{
${ }^{1}$ Dai học Y Dược Cần Tho

${ }^{2}$ Bênh viên An Giang

Chịu trách nhiệm chính: Nguyễn Ngọc Rạng

Email: nguyenngocrang@gmail.com

Ngày nhận bài: 24.4.2021

Ngày phản biên khoa học: 31.3.2021

Ngày duyệt bài: 9.4.2021
}

\section{Nguyễn Ngọc Rạng ${ }^{1}$, Dương Kim Thu ${ }^{2}$}

bị Sốt xuyết huyết dengue (SXHD). Mục tiêu: thiết lập bảng điểm dựa vào siêu âm đề tiên đoán SXHD có sốc Đối tượng và phương pháp: Đối tượng gồm 446 bệnh nhi SXHD có siêu âm, từ 1-14 tuổi, được truy cứu từ bệnh án lưu trũ tại bệnh viện An Giang. Dùng mô hình hồi qui logistic đảa biến để xác đinh các biến có khả năng tiên đoán sốc. Kết quả: Có tất cả 446 bệnh nhân (154 có sốc và 292 không sốc) được siêu âm trong giai đoạn tiền sốc. Tỉ lệ có tụ dịch ở 6 vị trí (túi Morison, túi cùng Douglas, dịch dưới bao gan, dịch tự do ổ bụng, dịch màng phối phải và trái) và dày thành túi mật (TTM) ở nhóm sốc cao hơn nhóm không 
sốc. Bảng điểm tiên đoán sốc SXH dựa vào siêu âm như sau:

\begin{tabular}{|c|c|c|}
\hline Vị trí & & Điếm \\
\hline \multirow{2}{*}{ Dày TTM > 5 mm } & Không & 0 \\
& Có & 1 \\
\hline \multirow{2}{*}{ Túi Morison } & Không & 0 \\
& Có & 1 \\
\hline \multirow{2}{*}{ Túi cùng Douglas } & Không & 0 \\
& Có & 2 \\
\hline \multirow{2}{*}{ Dịch dươi bao gan } & Không & 0 \\
& Có & 3 \\
\hline \multirow{2}{*}{ Dịch tự do ổ bụng } & Không & 0 \\
\hline \multirow{2}{*}{ Dịch màng phổi phải } & Có & 3 \\
\hline \multirow{2}{*}{ Dịch màng phổi trái } & Có & 0 \\
& Không & 1 \\
\hline & Có & 1 \\
\hline
\end{tabular}

Ở điểm cắt $>5$ điểm, giá trị để tiên đoán sốc SHXD có độ nhạy là $79,8 \%$ và độ đặc hiệu là $82,7 \%$. Kết luận: Siểu âm là một phưởng tiện không xâm lấn và có thể thực hiện tại giường bệnh để khảo sát nhanh dịch ổ bụng và màng phổi trong SXHD. Bảng điểm dựa vào siêu âm dịch ổ bụng có giá trị trong tiên đoán SXHD có sốc.

Tư khóa: Sốt xuất huyết dengue, siêu âm, bảng điểm siêu âm

\section{SUMMARY}

ESTABLISHMENT OF THE ULTRASOUND SCORING SYSTEM FOR PREDICTING THE DEVELOPMENT OF SHOCK IN CHILDREN WITH DENGUE HEMORRHAGIC FEVER

Background: Ultrasound is a simple tool for detecting peritoneal and pleural fluid in patient with Dengue fever (DF). Objective: to establish a ultrasound scoring system for predicting of developing shock in patients with DF. Methods: a retrospective study of 446 dengue patients with ultrasound, between 1 and14 years old, from the medical records stored at An Giang Hospital. Using multivariate logistic regression model to identify the variables capable of predicting shock. Results: A total of 446 patients (154 with shock and 292 without shock) were examined by ultrasound in the pre-shock phase. The incidence of fluid collections in 6 positions (Morison's pouch, Pouch of Douglas' cul-de-sac, subcapsular space, abdominal free fluid, right and left pleural fluid) and gallbladder wall thickening (GBWT) in DF patients with shock was higher than in DF patients without shock. The ultrasound scoring system for predicting shock was as follows:

\begin{tabular}{|c|c|c|}
\hline Regions & & Points \\
\hline \multirow{2}{*}{ GBWT $\geq 5 \mathrm{~mm}$} & No & 0 \\
\cline { 2 - 3 } & Yes & 1 \\
\hline Morison's & No & 0 \\
\cline { 2 - 3 } pouch & Yes & 1 \\
\hline $\begin{array}{c}\text { Subcapsular } \\
\text { space }\end{array}$ & No & 0 \\
\hline Douglas' cul- & Yes & 3 \\
\cline { 2 - 3 } de-sac & No & 0 \\
\hline Floating bowel & Yes & 2 \\
\hline
\end{tabular}

\begin{tabular}{|c|c|c|}
\hline loops & Yes & 3 \\
\hline Right pleural & No & 0 \\
\cline { 2 - 3 } effusion & Yes & 1 \\
\hline Left pleural & No & 0 \\
\cline { 2 - 3 } effusion & Yes & 1 \\
\hline & $\begin{array}{c}\text { Ultrasound score is } \\
\text { sum of all points }\end{array}$ & $(0-12)$ \\
\hline
\end{tabular}

At the cut-off $>5$ points, the value of predicting shock in DF patients had sensitivity of $79.8 \%$ and specificity of $82.7 \%$.Conclusion: Sonography provides a fast, portable, and noninvasive method for detecting fluid collections in peritoneal and pleural cavities. The use of ultrasound scoring system is of value for predicting of developing shock.

Keywords: Dengue fever, ultrasound, The ultrasound scoring system

\section{I. ĐẶT VẤN ĐỀ}

Bệnh Sốt xuất huyết dengue (SXHD) là bênh nhiễm khuẩn cấp tính gây ra do virus dengue gồm có 4 típ huyết thanh DEN-1, DEN-2, DEN-3 và $D E N-4$, được truyên bệnh chủ yếu do muỗi Aedes aegypti. Bệnh SXHD là một vấn đề sức khỏe cộng đồng nghiêm trọng ở hâu hết các quốc gia Đông Nam Á và Tẩy Thái Bình Dương [1]. Tại Việt Nam, từ năm 2007 đến nay, trung bình mỗi năm có 91 nghìn trường hợp SXHD nhập viện [2].

Cơ chế sinh lý bênh chính trong SXHD là sinh lý bệnh chính là tăng tính thấm thành mạch và rối loạn đông cầm máu. Tăng tính thấm thành mạch làm thất thoát huyết tương từ khoang mạch máu vào các khoảng kẽ, ổ bụng và màng phổi.Dung tích hồng câu (DTHC) là môt chỉ số đơn giản để ước tính mức độ rò rỉ huyết tương, tuy nhiên DTHC không tăng ở bệnh nhân thiếu máu hoặc xuất huyết.

Siêu âm đã được sử dụng từ những năm 1990 để khảo sát dịch ổ bung trong chấn thương bụng kín với độ nhạy và độ đặc hiệu cao [3],[4]. Hiện nay, siêu âm cũng đã được sử dụng thường xuyên để phát hiên các tụ dịch trong ổ bung và màng phổi ở bệnh nhân SXHD [5], [6]. Ngoài ra, dựa vào mức độ thoát dịch phát hiện trên siêu âm có thể dự đoán mức độ nặng của bệnh [6].

Mục đích của nghiên cứu này nhằm thiết lập một bảng điểm để tiên đoán sốc ở bệnh nhân SXHD bằng cách sử dụng siêu âm để phát hiện dịch tự do trong ổ bụng và màng phổi.

\section{II. ĐỐI TƯỢNG VÀ PHƯƠNG PHÁP NGHIÊN CỨU}

2.1 Đối tượng nghiên cứu. Gồm tất cả các hồ sơ bệnh nhân (BN) từ 1-14 tuổi được lưu trữ tại Khoa nhi, Bệnh viện Sản Nhi An Giang trong chương trình hợp tác nghiên cứu thuốc chủng ngừa SXHD với công ty Sanofi. Tất cả các BN 
này nhập viện vào khoa Nhi bệnh viện An giang vào năm 2003-2004 với chẩn đoán là SXHD, được xác định bằng phân lập virus cho các trường hợp nhập viện trước ngày 5 của bệnh và làm xét nghiệm Mac-Elisa (IgM và IgG) 2 lần cho tất cả các trường hợp còn lại. Trong số này có $446 \mathrm{BN}$ được siêu âm ổ bụng vào thời điểm tiền sốc (vào ngày 4-5 của bệnh). Chẩn đoán sốc SXHD dựa vào tiêu chí của WHO 1997 [1].

2.2 Phương pháp nghiên cứu. Dùng máy siêu âm Toshiba Capasee với đầu dò $3,75 \mathrm{MHz}$ để khảo sát dịch ổ bụng và mang phổi. Mỗi $\mathrm{BN}$ nếu không sốc được siêu âm từ ngày thứ 3 đến ngày thứ 5 của bệnh. BN có sốc chỉ siêu âm một lần. Khảo sát tụ dịch ở 6 vị trí gồm túi Morison, túi cùng Douglas, dịch dưới bao gan, dịch tự do ổ bụng, dịch màng phổi phải và trái. Riêng thành túi mật (TTM) được định nghĩa là dày TTM khi có bề dày $\geq 5 \mathrm{~mm}$.

2.3 Xử lý dữ liệu: Các số liệu định tính được trình bày bằng số lượng và tỉ lệ \%. Dùng phép kiểm khi bình phương hoặc Fischer's exact để so sánh 2 tỉ lệ. Dùng mô hình hồi qui logistic đa biến để xem hê số hồi qui và tỉ số chênh của các biến. Các tỉ số chênh được làm tròn để thiết lập bảng điểm dựa vào siêu âm tiên đoán sốc. Đánh giá sự hợ lý của mô hình hồi qui bằng phép kiểm Hosmer và Lemeshow. Dùng đường cong ROC và chỉ số Youden để xác định điểm cắt tối ưu phân biệt giữa nhóm có và không có sốc. Tính diện tích dưới đường cong (AUC), độ nhạy và độ đặc hiệu theo điểm cắt tối ưu này. Các test thống kê khác biệt có ý nghĩa thống kê khi p $<0,05$. Dùng phần mềm SPSS 22.0 trong Windows để xứ lý thống kê.

\section{KẾT QUẢ NGHIÊN CỨU}

Tổng cộng có 446 trường hợp được siêu âm, tuổi trung bình là $7,8 \pm 3,5$ tuổi, nam chiếm $51 \%$. Số BN có sốc là $154(34,5 \%)$ và số $B N$ không sốc là 292 (65,5\%). Tỉ lệ có tụ dịch tại các vị trí trong ổ bụng và màng phổi được trinh bày ở bảng 1.

Bảng 1. Tỉ lê phân trăm có tụ dịch ở các vị trí trong ô bung và màng phổi giữa 2 nhóm có sốc và không sốc

\begin{tabular}{|c|c|c|c|}
\hline & $\begin{array}{c}\text { Không sốc } \\
(\mathbf{n = 2 9 2})\end{array}$ & $\begin{array}{c}\text { Có sốc } \\
(\mathbf{n = 1 5 4})\end{array}$ & $\begin{array}{c}\mathbf{P} \\
\text { value }\end{array}$ \\
\hline $\begin{array}{c}\text { Dày TTM } \geq \\
5 \mathrm{~mm}\end{array}$ & $92(31,5 \%)$ & $\begin{array}{c}129 \\
(83,8 \%)\end{array}$ & $\begin{array}{c}< \\
0,001\end{array}$ \\
\hline $\begin{array}{c}\text { Túi } \\
\text { Morison }\end{array}$ & $65(22,3 \%)$ & $\begin{array}{c}123 \\
(79,9 \%)\end{array}$ & $\begin{array}{c}< \\
0,001\end{array}$ \\
\hline $\begin{array}{c}\text { Túi cùng } \\
\text { Douglas }\end{array}$ & $69(23,6 \%)$ & $\begin{array}{c}122 \\
(79,2 \%)\end{array}$ & $\begin{array}{c}< \\
0,001\end{array}$ \\
\hline
\end{tabular}

\begin{tabular}{|c|c|c|c|}
\hline $\begin{array}{c}\text { Dưới bao } \\
\text { gan }\end{array}$ & $48(16,5 \%)$ & $\begin{array}{c}113 \\
(73,4 \%)\end{array}$ & $\begin{array}{c}< \\
0,001\end{array}$ \\
\hline $\begin{array}{l}\text { Dịch tự do } \\
\text { ổ bụng }\end{array}$ & $39(13,4 \%)$ & $\begin{array}{c}103 \\
(66,9 \%)\end{array}$ & $\begin{array}{c}< \\
0,001\end{array}$ \\
\hline $\begin{array}{l}\text { Màng phối } \\
\text { phải }\end{array}$ & 46( & $\begin{array}{c}96 \\
(62,3 \%)\end{array}$ & $\begin{array}{c}< \\
0,001\end{array}$ \\
\hline $\begin{array}{l}\text { Màng phối } \\
\text { trái }\end{array}$ & $18(06,2 \%)$ & $\begin{array}{c}49 \\
(31,3 \%)\end{array}$ & 0,001 \\
\hline
\end{tabular}

Tất cả các biến có sự khác biêt giữa nhóm không sốc và có sốc được đưa vào mô hình hồi qui logistic đa biến (bảng 2).

Bảng 2. Hệ số hôi quí và tỉ số chênh các biến trong mô hình hồi qui logistic đảa biến

\begin{tabular}{|c|c|c|}
\hline & $\begin{array}{c}\text { Hệ số hồi } \\
\text { qui B }\end{array}$ & $\begin{array}{c}\text { OR và KTC } \\
\mathbf{9 5 \%}\end{array}$ \\
\hline Dày TTM $\geq 5 \mathrm{~mm}$ & 0,276 & $1,3(0,5-3,1)$ \\
\hline Túi Morison & 0,339 & $1,4(0,5-3,8)$ \\
\hline Túi cùng Douglas & 0,905 & $2,4(1,1-5,2)$ \\
\hline Dưới bao gan & 1,198 & $3,3(1,5-7,0)$ \\
\hline Dịch tự do ố bụng & 1,187 & $3,2(1,4-7,0)$ \\
\hline Màng phối phải & 0,566 & $1,7(0,7-4,1)$ \\
\hline Màng phối trái & 0,379 & $1,4(0,6-3,1)$ \\
\hline
\end{tabular}

Trong phân tích hồi qui đa biến hai vị trí tụ dịch có hệ số hồi qui cao nhất là dịch dưới bao gan và dịch tự do ổ bụng với tỉ số chênh bằng 3 (làm tròn), kể tiếp là dịch ở túi cùng Douglas có tỉ số chênh làm tròn bằng 2. Các vị trí còn lại (túi Morison, dịch màng phổi trái, dịch màng phổi trái) và dày TTM có tî số chệnh làm tròn bằng 1 . Thiết lập bảng điểm tiên đoán sốc dựa vào siêu âm (bảng 3)

Bảng 3. Bảng điểm tiên đoán sốc SXHd dựa vào siêu âm

\begin{tabular}{|c|c|c|}
\hline Vị trí & & Điếm \\
\hline Dày TTM $\geq 5 \mathrm{~mm}$ & Không & 0 \\
& Có & 1 \\
\hline Túi Morison & Khống & 0 \\
& Có & 1 \\
\hline Túi cùng Douglas & Khống & 0 \\
& Có & 2 \\
\hline Dịch dươi bao gan & Khống & 0 \\
\hline Dịch tự do ổ bụng & Cón & 3 \\
\hline Dịch màng phổi phải & Cón & 0 \\
& Khống & 0 \\
\hline Dịch màng phổi trái & Khống & 1 \\
\hline & Có & 1 \\
\hline & Tống điếm & $\mathbf{1 2}$ \\
\hline
\end{tabular}

Dùng đường cong ROC và chỉ số Youden để xác định điểm cắt tối ưu phân biệt giữa nhóm có và không có sốc.

Diện tích dưới đường cong ROC bằng 0,813 (KTC 95\%: 0,769-0,858)(p<0,001)

Với điểm cắt $>5$ điểm, độ nhạy và độ đặc hiệu để chẩn đoán sốc lần lượt là 79,8\% và $82,7 \%$. 


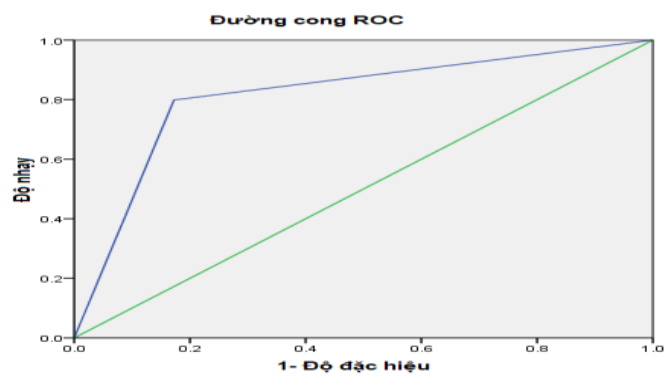

Biểu đồ. Diện tích dưới đường cong ROC tiên đoán sốc SXHD

\section{BÀN LUÂN}

Trong nghiên cứu này, hình ảnh siêu âm cho thấy có tụ dịch ở các vùng thấp trong ổ bụng và màng phổi. Những kinh nghiệm trước đây trong chấn thương bụng kín, dịch thường thấy ở túi Morison, túi cùng Douglas và rãnh cạnh đại tràng [3]. Trong SHXD, các dấu hiệu được thấy trên siêu âm gồm dày TTM, dịch ở túi Morison, túi cùng Douglas, dịch xung quanh gan và dịch tự do trong ổ bụng. Ngoài ra còn thây dịch ở màng phổi phải và trái [5], [6]. Trong nghiên cứu của chúng tôi, trong SXHD không sốc, dịch thường thấy ở túi Morison, túi cùng Douglas và màng phổi phải với lượng ít. Ngoài ra còn thấy dấu hiệu dày TTM. Trong SXHD có sốc, thường thấy dịch tự do trong ổ bụng và dịch màng phổi trái, phù hợp với nhận xét của Setiawan và cộng sự (CS) [6], [7]. Đặc biệt tụ dịch dưới bao gan hoặc vùng giữa cơ hoành phải và gan dịch dưới bao gan rất dễ phát hiện và có giá trị cao trong tiên đoán sốc (hình 1)

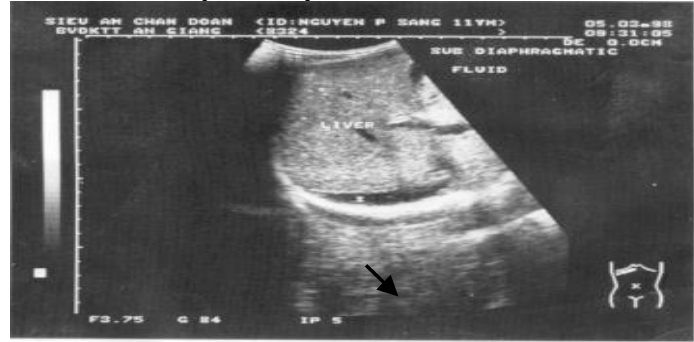

Hình 1. Dâu hiệu tụ dịch dưới bao gan

Nhiều nghiên cứu trước đây thường chụp phim $X$ quang tư thế nằm nghiêng phải để xem dịch màng phổi [8], tuy nhiên dịch màng phổi khó thây trên phim $X Q$, đặc biệt khi lượng dịch còn ít. Theo Setiawan và CS [7], $30 \%$ SXHD không sốc và $95 \%$ SXHD có sốc thấy có dịch màng phổi phải trên siêu âm. Dịch màng phổi trái thường ít thây trong SXHD không sốc. Theo Pramuljo và CS $[5\}$, ở BN có sốc thì $100 \%$ thấy dịch ở màng phổi phải và $68,5 \%$ thây dịch ở màng phổi trái [5]. Trong nghiên cứu này, chúng tôi nhận thấy tỉ lệ tụ dịch ở các vị trí thấp trong ổ bụng và dịch màng phổi cao hơn trong nhóm SXHD có sốc trong giai đoạn tiền sốc, thường xảy ra vào ngảy 4-5 của bệnh. (bảng 1 ).

Dùng mô hình hồi qui logistic đa biến, cho điểm từng vị trí theo hệ số hồi qui và tỉ số chệnh, chúng tôi thiết lập bảng điêm từ $0-12$ điểm. Các bệnh nhân SXHD nào có điểm siêu âm $>5$ điểm sẽ có nguy cơ vào sốc cao hơn với độ nhạy là $79.8 \%$ và độ đặc hiệu là $82,7 \%$. Trước đây, Setiawan và CS [6] cũ̃ng thiết lập bảng điểm siêu âm để tiên đoán sốc SXHD, tuy nhiên số mẫu quá nhỏ (45 trường hợp) và không dùng phân tích đa biến để tính hệ số hồi qui, vì vậy bảng điểm này í được tin cậy [6].

Nghiên cứu này còn nhiều han chế vì đươoc thực hiện tại một trung tâm, một số bệnh nhân được siêu ẩm khi đã vào sốc. Tuy vậy, nghiên cứu này có những điểm mạnh gồm cỡ mẫu lớn, thiết lập bảng điểm theo hệ số hồi qui trong phân tích đa biến và kiểm chứng bằng diện tích dưới đường cong ROC.

\section{KẾT LUÂ̂N}

Siêu âm là một phương tiện không xâm lấn, nhanh và có thể thực hiện tại giường bệnh để khảo sát dịch ổ bụng và màng phổi trong SXHD. Với bảng điểm siêu âm có thang điểm từ $0-12$ điểm, các bệnh nhân SXHD nào có điểm siêu âm $>5$ điểm sẽ có nguy cơ vào sốc cao hơn với độ nhạy là 79,8\% và độ đặc hiệu là $82,7 \%$.

\section{TÀI LIẸU THAM KHẢO}

1. Halstead SB (1997) Epidemiology of Dengue and Dengue Hemorrhagic Fever. In: Gubler DJ, Kuno G, Editors: Dengue and Dengue Hemorrhagic Fever. Cambridge: CAB International; $p$ 23-44.

2. Hung TM, Clapham HE, Bettis AA, et al. (2018) The Estimates of the Health and Economic Burden of Dengue in Vietnam. Trends Parasitol. 34(10): 904-918.

3. Hahn DD, Offerman SR, Holmes JF. (2002) Clinical importance of intraperitoneal fluid in patients with blunt intra-abdominal injury. Am J Emerg Med. 20(7):595-600.

4. McKenney MG, Martin L, Lentz K, et al. (1996) 1000 consecutive ultrasounds for blunt abdominal trauma. J Trauma. 40:607-612.

5. Pramuljo HS, Harun SR. (1991) Ultrasound findings in dengue haemorrhagic fever. Pediatr Radiol; 21:100-102.

6. Setiawan MW. Early diagnosis of atypical Dengue hemorrhagic fever. Itrasound international. 1995; 1:135-140.

7. Setiawan MW, Samsi TK, Wulur $H$, et al. (1998) Dengue haemorrhagic fever: ultrasound as an aid to predict the severity of the disease. Pediatr Radiol; 28:1-4

8. Nimmannitya S. (1987). Clinical spectrum and management of dengue haemorrhagic fever. Southeast Asian J Trop Med Public Health.18(3):392-7. 